Article

\title{
Export of Rgg Quorum Sensing Peptides is Mediated by the PptAB ABC Transporter in Streptococcus Thermophilus Strain LMD-9
}

\author{
Abarna Lingeswaran, Coralie Metton, Céline Henry, Véronique Monnet, Vincent Juillard $\mathbb{D}$ and \\ Rozenn Gardan * \\ Université Paris-Saclay, INRAE, AgroParisTech, Micalis Institute, 78350, Jouy-en-Josas, France; \\ abarna.lingeswaran@inrae.fr (A.L.); coraliemetton@yahoo.fr (C.M.); celine.henry@inrae.fr (C.H.); \\ veronique.monnet@inrae.fr (V.M.); vincent.juillard@inrae.fr (V.J.) \\ * Correspondence: rozenn.gardan@inrae.fr
}

Received: 23 July 2020; Accepted: 17 September 2020; Published: 19 September 2020

check for updates

\begin{abstract}
In streptococci, intracellular quorum sensing pathways are based on quorum-sensing systems that are responsible for peptide secretion, maturation, and reimport. These peptides then interact with Rgg or ComR transcriptional regulators in the Rap, Rgg, NprR, PlcR, and PrgX (RRNPP) family, whose members are found in Gram-positive bacteria. Short hydrophobic peptides (SHP) interact with Rgg whereas ComS peptides interact with ComR regulators. To date, in Streptococcus thermophilus, peptide secretion, maturation, and extracellular fate have received little attention, even though this species has several (at least five) genes encoding Rgg regulators and one encoding a ComR regulator. We studied pheromone export in this species, focusing our attention on PptAB, which is an exporter of signaling peptides previously identified in Enterococcus faecalis, pathogenic streptococci and Staphylococcus aureus. In the S. thermophilus strain LMD-9, we showed that PptAB controlled three regulation systems, two SHP/Rgg systems (SHP/Rgg 1358 and SHP/Rgg 1299 ), and the ComS/ComR system, while using transcriptional fusions and that PptAB helped to produce and export at least three different mature SHPs $\left(\mathrm{SHP}_{1358}, \mathrm{SHP}_{1299}\right.$, and $\left.\mathrm{SHP}_{279}\right)$ peptides while using liquid chromatography-tandem mass spectrometry (LC-MS/MS). Using a deep sequencing approach (RNAseq), we showed that the exporter PptAB, the membrane protease Eep, and the oligopeptide importer Ami controlled the transcription of the genes that were located downstream from the five non-truncated $\mathrm{rgg}$ genes as well as few distal genes. This led us to propose that the five non-truncated $\operatorname{sh} p / r g g$ loci were functional. Only three sh $p$ genes were expressed in our experimental condition. Thus, this transcriptome analysis also highlighted the complex interconnected network that exists between SHP/Rgg systems, where a few homologous signaling peptides likely interact with different regulators.
\end{abstract}

Keywords: signaling peptide; streptococci; RRNPP; transcriptional regulation

\section{Highlights}

- $\quad$ PptAB exports signaling peptides from intracellular quorum sensing systems in Streptococcus thermophilus;

- $\quad$ PptAB only exports mature signaling peptides;

- $\quad$ in the $S$. thermophilus strain LMD-9, PptAB, Eep (a protease), and Ami (a peptide importer) are involved in a QS mechanism that controls the expression of genes located downstream all rgg genes but also of a few distal targets; and, 
- at the strain level, crosstalk between the SHP/Rgg systems likely occurs and involves a few SHP signaling peptides that interact with multiple Rgg regulators.

\section{Introduction}

Quorum sensing (QS) is a cell-cell communication mechanism that is used by bacteria to trigger the expression of an entire set of genes when population levels exceed a certain threshold of cell density [1]. Functions that are controlled by QS are very diverse, ranging from luminescence in Vibrio fischeri [2], natural transformation in streptococci [3], bacteriocin production in lactococci and bacilli [4], and virulence in Staphylococcus aureus [5]. The QS circuit is similar across all bacteria. First, a signaling molecule, also called an autoinducer, is released into the extracellular environment, where it accumulates. Once it reaches a threshold concentration, its presence is detected by a sensor protein, which leads cells to modulate the expression of target genes. In Gram-positive bacteria, the signaling molecules are mainly autoinducing peptides (AIPs), also called pheromones. Most are ribosomally synthesized from short coding sequences (short CDSs), transformed into their mature forms, exported, and sometimes experience cyclization or the modification of amino acid residues. Some AIPs are produced via the proteolytic degradation of lipoproteins and, more specifically, their secretory signal peptides [6]. There are two general activation pathways. The first pathway is a two-component system that comprises a histidine kinase and a response regulator. The histidine kinase senses the presence of AIPs in the extracellular environment. A phosphorylation cascade involving the histidine kinase and the response regulator leads to the activation or repression of target gene transcription $[5,7,8]$. In the second pathway also called intracellular pathway, the presence of AIPs is sensed within the cell after they have been internalized by an oligopeptide permease transport system composed of $\mathrm{ABC}$-family transporters. Once in the cell, AIPs interact with transcriptional regulators or Rap proteins, both members of the RRNPP family (which stands for Rap, Rgg, NprR, PlcR, and PrgX), thereby modifying the latter's activity and, consequently, the expression of target genes $[9,10]$. Rap proteins mediate sporulation, competence, and the production of degradative enzymes in bacilli [11]. PlcR and NprR help to control virulence and necrotrophism in bacteria of the cereus group [12]. PrgX-like proteins are involved in plasmid transfer in enterococci [13]. The function of the Rgg-like regulators found in streptococci will be described below. To date, research focusing on this process has largely examined the interactions between RRNPP proteins and their cognate AIPs [10]. It has revealed that all of the members of the RRNPP family share a similar core structure and they have a tetratricopeptide domain in their C-terminus [14,15]. This domain is involved in the interaction with their cognate AIPs. In addition, the transcriptional regulators have a helix-turn-helix DNA-binding domain at their $\mathrm{N}$-terminus. Interestingly, members of the RRNPP family each undergo distinct structural changes following binding with their specific AIPs [10].

Far less is known about the secretion, maturation, and extracellular fate of the AIPs, but these processes appear to be somewhat specific for each member of the RRNPP family. AIPs that are associated with Rap, PlcR, and NprR proteins have a particular secretion signal peptide in their $\mathrm{N}$-terminus that is likely targeted for the Sec-dependent export pathway, resulting in the AIPs' secretion and maturation via a signal peptidase. Additional extracellular proteases mediate further maturation: they have been identified for some AIPs of Rap proteins [11,16] and the AIP of the PlcR regulator [17]. Most, however, remain unknown. Peptides associated with PrgX-like regulators fall into one of two categories: (1) they are inhibitory peptides encoded by short genes or (2) they are activating peptides that are embedded in lipoprotein secretion signal peptides that are released outside the cell during lipoprotein export. Activating peptides are matured by serial peptidases, which include a lipoprotein signal peptidase, a transmembrane protease, named Eep, and additional undescribed exoproteases. Eep appears to be capable of maturing inhibitory peptides [18]. By screening a transposon mutant library, the researchers identified PptAB, a peptide exporter of $\mathrm{ABC}$ transporters, and determined that it was the exporter of three different activating peptides in E. faecalis [19]. The final members of the RRNPP family—Rgg and ComR—are Rgg-like regulators. Rgg regulators help to produce modified 
secreted peptides [20], biofilms and lysozyme resistance [21-23], and mediate pathogenicity [24,25]. ComR regulators help to mediate competence and bacteriocin production [3,26]. Rgg regulators are associated with AIPs, called short hydrophobic peptides (SHPs); ComR regulators are associated with ComS peptides, called sigX-inducing peptides (XIPs) in their mature form. Eep causes the maturation of SHPs, as observed for one SHP in Streptococcus thermophilus [27]; for SHP2 and SHP3 in Streptococcus pyogenes [21]; and, for the RovS-associated SHP in Streptococcus agalactiae [24]. Eep also controls the maturation of ComS in S. thermophilus [28], but only plays a contributing role in S. mutans [29]. Finally, PptAB is involved in the export of SHP2 and SHP3 in S. pyogenes [30] and of the RovS-associated SHP in S. agalactiae [24]; however, it only contributes to the export of mature ComS in Streptococcus mutans [30].

S. thermophilus plays a major role in the food industry, because it is a starter employed in massive quantities to manufacture yoghurt, Swiss-type cheeses, and Italian-type cheeses. It is also a useful representative of the genus Streptococcus with which to study QS: S. thermophilus encodes many QS systems in its genome, including at least five different SHP/Rgg systems [27] and one ComS/ComR system [31]. We have deciphered two different SHP/Rgg systems in the S. thermophilus wild-type strain LMD-9. The first system, SHP/Rgg 1358 , controls the transcription of the $s h p_{1358}$ gene and at least three genes that are involved in the production of a cyclic secreted peptide, called streptide, which are located downstream from the $r g g_{1358}$ gene $[20,27,32]$. The second system, SHP/Rgg 1299 , controls the transcription of the $s h p_{1299}$ gene and a putative operon located downstream from the $r g g_{1299}$ gene whose function remains undetermined [33]. Because little is known about the process by which the AIPs of the two SHP/Rgg systems and the ComS/ComR system are exported, we characterized the role of the PptAB exporter in these three QS systems with transcriptional fusions and a LC-MS/MS approach for three $\mathrm{SHP}_{1358}, \mathrm{SHP}_{1299}$ and $\mathrm{SHP}_{279}$. We used a transcriptomic approach to explore genome-level expression of the target genes in all functional RRNPP QS systems.

\section{Materials and Methods}

\subsection{Bacterial Strains and Growth Conditions}

Our study strain was the $S$. thermophilus wild-type strain LMD-9 (hereafter, the wild-type strain). It has two plasmids-plasmid 1 and plasmid 2 [34]. Table 1 lists the mutant strains that we constructed using this wild-type strain. S. thermophilus was grown at $37^{\circ} \mathrm{C}$ or $42{ }^{\circ} \mathrm{C}$ in either M17 medium (Difco) supplemented with $10 \mathrm{~g} \mathrm{~L}^{-1}$ lactose (M17lac) or in a chemically defined medium (CDM) [35]. Escherichia coli was grown at $37^{\circ} \mathrm{C}$ in Luria-Bertani broth with shaking. Agar (1.5\%) was added to the media, as needed. When required, antibiotics were added to the media at the following final concentrations: erythromycin at $150 \mu \mathrm{g} \mathrm{mL}^{-1}$ for E. coli and at $5 \mu \mathrm{g} \mathrm{mL} \mathrm{L}^{-1}$ for S. thermophilus and kanamycin at $1 \mathrm{mg}$ $\mathrm{mL}^{-1}$ for $S$. thermophilus. 
Table 1. S. thermophilus strains used in this study.

\begin{tabular}{|c|c|c|c|c|}
\hline Strain & Genotype & Resistance $^{a}$ & Description $^{b}$ & Source or Reference \\
\hline LMD-9 & wild-type & & & [34] \\
\hline СВ001 & blp:: $\mathrm{P}_{\text {com } \mathrm{X}}-\operatorname{lux} A B$ & & & [31] \\
\hline TIL773 & $\Delta e e p$ & & & [27] \\
\hline TIL883 & $\triangle a m i C D E$ & & & [20] \\
\hline TIL1038 & blp:: $\mathrm{P}_{\text {shp1299-lux } A B \text { aphA3 }}$ & $\mathrm{Km}$ & & {$[33]$} \\
\hline TIL1165 & blp:: $\mathrm{P}_{\operatorname{sh} p 1358-l u x A B}$ & & & [27] \\
\hline TIL1179 & pBV5030:: $\mathrm{P}_{32}$ & Er & & [28] \\
\hline TIL1213 & $\triangle a m i C D E$ pBV5030:: $\mathrm{P}_{32}-s h p_{1358}$ & Er & & [27] \\
\hline TIL1486 & pptAB::erm & Er & PCR fragment pptAB::erm $\rightarrow$ LMD-9 & This study \\
\hline TIL1488 & blp:: $\mathrm{P}_{\text {comX }}$-luxAB pptAB::erm & Er & TIL1486 DNA $\rightarrow$ CB001 & This study \\
\hline TIL1489 & blp:: $\mathrm{P}_{\text {shp1358-luxAB pptAB::erm }}$ & Er & TIL1486 DNA $\rightarrow$ TIL1165 & This study \\
\hline TIL1491 & $\begin{array}{c}\text { blp::P } \mathrm{P}_{\text {shp1299-luxAB aphA3 }} \\
\text { pptAB::erm }\end{array}$ & Er Km & TIL1486 DNA $\rightarrow$ TIL1038 & This study \\
\hline TIL1557 & blp::P $\mathrm{P}_{p t A B}-l u x A B$ aphA3 & $\mathrm{Km}$ & pGICB004a:: $P_{p p t A B} \rightarrow$ LMD-9 & This study \\
\hline TIL1558 & $\triangle p p t A B$ & & $\mathrm{pG}^{+}$host9::updown.ppt $A B \rightarrow$ LMD-9 & This study \\
\hline TIL1559 & pBV5030:: $\mathrm{P}_{32}-\operatorname{sh} p_{1358}$ & Er & pBV5030::P $\mathrm{P}_{32}-\operatorname{sh}_{1358} \rightarrow$ LMD-9 & This study \\
\hline TIL1560 & comR::aphA3 & $\mathrm{Km}$ & $\mathrm{pG}^{+}$host9::updown.comRaphA3 $\rightarrow$ LMD-9 & This study \\
\hline TIL1561 & $\Delta$ eеp comR::aphA3 & $\mathrm{Km}$ & $\mathrm{pG}^{+}$host9::updown.comRaphA3 $\rightarrow$ TIL773 & This study \\
\hline TIL1562 & $\triangle p p t A B$ comR::aphA3 & $\mathrm{Km}$ & pG $^{+}$host9::updown.comRaphA3 $\rightarrow$ TIL1558 & This study \\
\hline TIL1563 & $\Delta p p t A B$ pBV5030:: $\mathrm{P}_{32}-s h p_{1358}$ & Er & pBV5030:: $\mathrm{P}_{32}-s h p_{1358} \rightarrow$ TIL1558 & This study \\
\hline TIL1564 & $\triangle a m i C D E$ comR::aphA3 & $\mathrm{Km}$ & $\mathrm{pG}^{+}$host9::updown.comRaphA3. $\rightarrow$ TIL883 & This study \\
\hline TIL1565 & $\Delta p p t A B$ pBV5030:: $\mathrm{P}_{32}$ & Er & pBV5030:: $\mathrm{P}_{32} \rightarrow$ TIL1558 & This study \\
\hline
\end{tabular}

${ }^{\mathrm{a}} \mathrm{Km}$ and Er = resistance to kanamycin and erythromycin, respectively. ${ }^{\mathrm{b}}$ The arrows indicate construction via transformation with chromosomal DNA or a plasmid. 


\subsection{DNA Manipulation and Sequencing}

Restriction enzymes, T4 DNA ligase (New England Biolabs), and Phusion DNA polymerase (Finnzymes) were used in accordance with the manufacturers' instructions. Standard methods were used to carry out DNA purification, restriction digestion, PCR, ligation, and sequencing. Table S1 lists the oligonucleotides we used (Eurofins). The E. coli strain TG1 rep $A^{+}$was used as the host for the cloning experiments [36]. S. thermophilus was transformed while using natural competent cells [36] with the addition of synthetic competence peptide (ComS, LPYFAGCL) at a concentration of $1 \mu \mathrm{M}$ when required or using electrocompetent cells [20] when the strains where not naturally competent. The plasmids used are listed in Table S2.

\subsection{Construction of the Mutant Strains}

The overlapping PCR method was used to delete the $p p t A B$ genes and replace them with an erythromycin cassette ( $\mathrm{erm}$ ) as follows. The erm cassette was amplified via PCR with the oligonucleotides Erm-F and Erm-R and using $\mathrm{pG}^{+}$host9 as a template [37]; it was fused to fragments located upstream and downstream from the $p p t A B$ genes, also using PCR. The upstream and downstream fragments were amplified with the oligonucleotides pptABe_up-F/pptABe_up-R and pptABe_down-F/pptABe_down-R, respectively, while using chromosomal DNA from the wild-type strain as a template. The resulting PCR fragment was used to transform the wild-type strain, leading to the construction of TIL1486

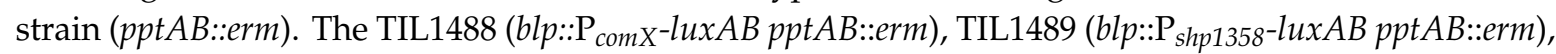

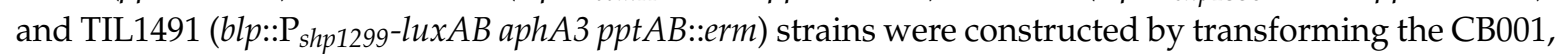
TIL1165, and TIL1038 strains, respectively, with chromosomal DNA from the TIL1486 strain.

We also constructed a mutant, the TIL1558 strain $(\triangle p p t A B)$, in which we deleted an internal fragment of the $p p t A B$ genes via a double crossover event that involves the plasmid $\mathrm{pG}^{+}$host 9 . Thus, this mutant did not have an antibiotic resistance cassette. Briefly, the upstream and the downstream fragments of the $p p t A B$ genes were obtained via amplification using the primer pairs pptAB_up-F/pptAB_up-R and pptAB_down-F/pptAB_down-R. The overlapping PCR method was used to fuse both fragments. The resulting fragment was double digested using the restriction enzymes EcoRI and KpnI and then ligated into $\mathrm{pG}^{+}$host9 between the EcoRI and KpnI restriction sites. The resulting plasmid, $\mathrm{pG}^{+}$host9::updown.pptAB, was used to transform competent cells of the wild-type strain. The integration and excision of this plasmid [37] then generated the TIL1558 strain. In this mutant, the promoter of the $p p t A$ gene (including its ATG) and the last 74 bp of the pptB gene were conserved.

The presence of the plasmid pBV5030:: $\mathrm{P}_{32}-\operatorname{sh} p_{1358}$ allowed for the expression of the $s h p_{1358}$ gene under the strong $\mathrm{P}_{32}$ promoter. This plasmid was used to transform the wild-type strain and the TIL1558 strain, resulting in the TIL1559 and TIL1563 strains, respectively.

A variety of strains were created in which the $\operatorname{comR}$ gene was replaced with a kanamycin resistance cassette. First, the upstream and downstream regions of the comR gene were amplified using the primers comR_up-F/comR_up-R and comR_down-F/comR_down-R, respectively. The kanamycin cassette (aphA3) was amplified via PCR using the primers AphA3-F/AphA3-R and plasmid pKa as the template [38]. This cassette was inserted between the upstream and downstream fragments of the comR gene via overlapping PCR. The resulting fragment was double digested with the restriction enzymes EcoRI and XhoI and then ligated into $\mathrm{pG}^{+}$host9 between the related restriction sites, creating the plasmid $\mathrm{pG}^{+}$host9::updown.comRaphA3. The linearized plasmid that was obtained via digestion with the restriction enzyme NdeI was used to naturally transform the wild-type, TIL773 $(\triangle e e p)$, and TIL1558 ( $\triangle p p t A B)$ strains in order to generate the TIL1560 (comR::aphA3), TIL1561 ( $\triangle e e p$ comR::aphA3), and TIL1562 ( $\triangle p p t A B$ comR::aphA3) strains, respectively. The electrotransformation of the TIL883 strain ( $\triangle a m i C D E)$ with the plasmid $\mathrm{pG}^{+}$host9::updown.comRaphA3 and the subsequent processes of integration and excision generated the TIL1564 strain ( $\triangle a m i C D E$ comR::aphA3).

In order to study the expression of the $p p t A B$ genes, a derivative of pGICB004a, pGICB004a::P $P_{p t A B}$, was constructed, as follows. The promoter of the $p p t A B$ genes was amplified using the 
oligonucleotides PpptAB-SpeI and PpptAB-EcoRI; double digested with the restriction enzymes SpeI and EcoRI; and finally, ligated into pGICB004a between the related restriction sites. ScaI-linearized pGICB004a:: $\mathrm{P}_{p p t A B}$ was used to transform the wild-type strain, leading to the TIL1557 strain (blp:: $\mathrm{P}_{\text {pptAB }}$-luxAB aphA3).

Finally, the plasmid pBV5030:: $\mathrm{P}_{32}$ was used to transform the TIL1558 strain, resulting in the TIL1565 strain.

All of the constructions were verified by PCR and sequenced when necessary.

\subsection{Mass Spectrometry Analysis}

Liquid chromatography-tandem mass spectrometry (LC-MS/MS) was performed by coupling an LTQ-Orbitrap (Thermo Fisher Scientific, Waltham, MA, USA) with an UltiMate ${ }^{\mathrm{TM}} 3000$ RSLCnano System (Thermo Fisher Scientific); analyses were carried out at the PAPPSO platform (MICALIS, INRAE, Jouy-en-Josas, France). The strains were grown in $\mathrm{CDM}$ until they reached an $\mathrm{OD}_{600}$ of 0.8 , which corresponded to the end of the exponential growth phase. Three independent cultures (i.e., biological replicates) were grown for each strain studied. Supernatants were recovered via centrifugation (at 10,000 rpm and $4{ }^{\circ} \mathrm{C}$ for $10 \mathrm{~min}$ ). Samples $\left(4 \mu \mathrm{L}\right.$ ) were loaded at $20 \mu \mathrm{L} \mathrm{min}^{-1}$ on a precolumn ( $\mu$-Precolumn, $300 \mu \mathrm{m} \times 5 \mathrm{~mm}, \mathrm{C} 18$ PepMap100, $5 \mu \mathrm{m}, 100 \AA$, Thermo Fisher) and then washed with loading buffer. After $3 \mathrm{~min}$, the precolumn cartridge was connected to the separating column (Acclaim PepMap ${ }^{\circledR}, 75 \mu \mathrm{m} \times 500 \mathrm{~mm}, \mathrm{C} 18,3 \mu \mathrm{m}, 100 \AA$, Thermo Fisher). The flow rate was

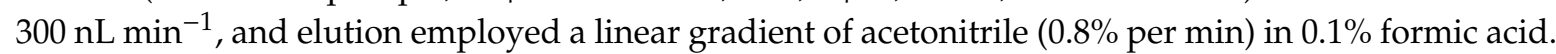
The eluted peptides were ionized with a spray voltage of $1.3 \mathrm{kV}$. A full MS scan (range: 400-2000 m/z) was performed while using the LTQ-Orbitrap. The full MS scans were automatically calibrated using the lock mass option and two dimethylcyclosiloxanes (391.284 and 536.165). The MS/MS analysis was carried out employing the collision-induced dissociation (CID) technique ( $40 \%$ collision energy), which was applied to three charge states $(+1,+2$, and +3$)$ and the eight most abundant ions (dynamic exclusion of $30 \mathrm{~s}$; minimal intensity threshold of $5 \times 10^{2}$ ). We manually extracted the ion current signals (XIC) with Xcalibur Qual Browser (v. 3.0.63). We analyzed the masses of mature $\mathrm{SHP}_{1358}$ (EGIIVIVVG), 898.561 Da, SHP 1299 (DIIIFPPFG), 1018.561 Da, SHP 279 (EGIIVIGVG), $856.514 \mathrm{Da}$, and the streptide (AKGDGWKVM with a cyclization between the first $\mathrm{K}$ and the $\mathrm{W}$ ), and 495.247 Da at a high level of resolution $(10 \mathrm{ppm})$. The presence of these mature forms was confirmed when we detected at least three masses that corresponded to fragments that were produced by MS2 fragmentation (accuracy of $0.5 \mathrm{Da})$.

\subsection{Luciferase Assays}

For the $p p t A B$ genes expression study, TIL1557 was the strain used (Figure 1, Table 1). For the results that are described in Figure 2, strains used were CB001, TIL1488, TIL1165, TIL1489, TIL1038, and TIL1491 (Table 1). The luciferase assays were carried out, as follows. The cells were grown overnight at $37^{\circ} \mathrm{C}$ in CDM or M17lac. The cultures were diluted to a final $\mathrm{OD}_{600}$ of $0.05 \mathrm{in} 1 \mathrm{~mL}$ of CDM or M17lac. As necessary, synthetic peptides, $\mathrm{SHP}_{1358}$ (EGIIVIVVG), $\mathrm{SHP}_{1299}$ (DIIIFPPFG), or ComS (LPYFAGCL), prepared in DMSO for the two SHPs or water for ComS were added at a final concentration of 1 $\mu \mathrm{M}$. We transferred $250 \mu \mathrm{L}$ of these diluted cultures to the wells of a covered sterile white microplate with a transparent bottom (Greiner). The cultures' $\mathrm{OD}_{600}$ and luminescence (as expressed in relative light units [RLU]) values were assessed at $37^{\circ} \mathrm{C}$ in an Infinite M200 spectroluminometer (Tecan), as previously described [31]. 


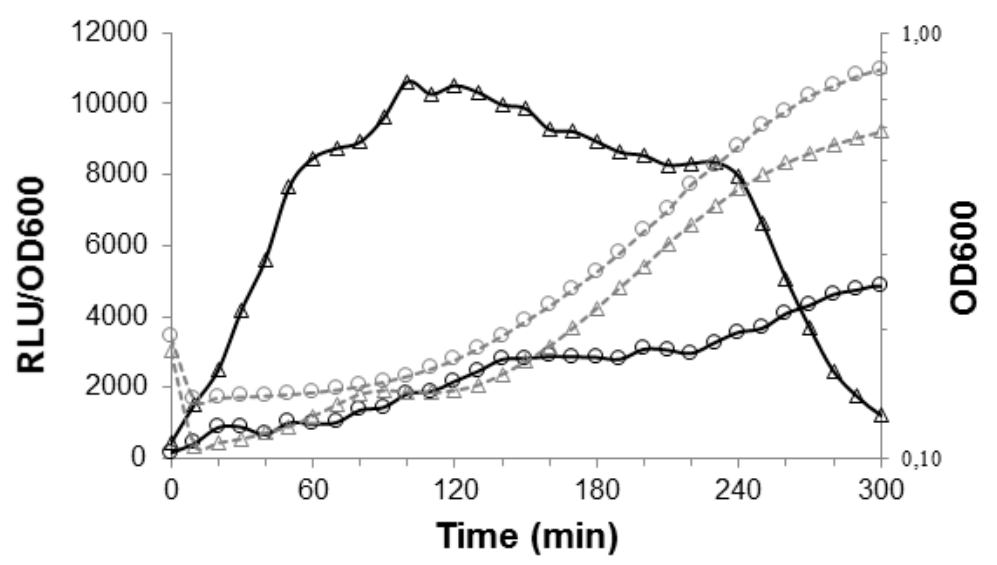

Figure 1. Growth and luciferase activity levels for the $S$. thermophilus TIL1557 strain ( $\mathrm{P}_{\text {pptAB }}$-luxAB) grown in chemically defined medium $(\mathrm{CDM})(\Delta)$ versus M17lac $(\bigcirc)$. The growth curves $\left(\mathrm{OD}_{600}\right)$ are depicted using gray dotted lines, and the relative levels of luciferase activity $\left(R L U / O D_{600}\right)$ are depicted using black solid lines. Data shown are representative of three independent experiments.
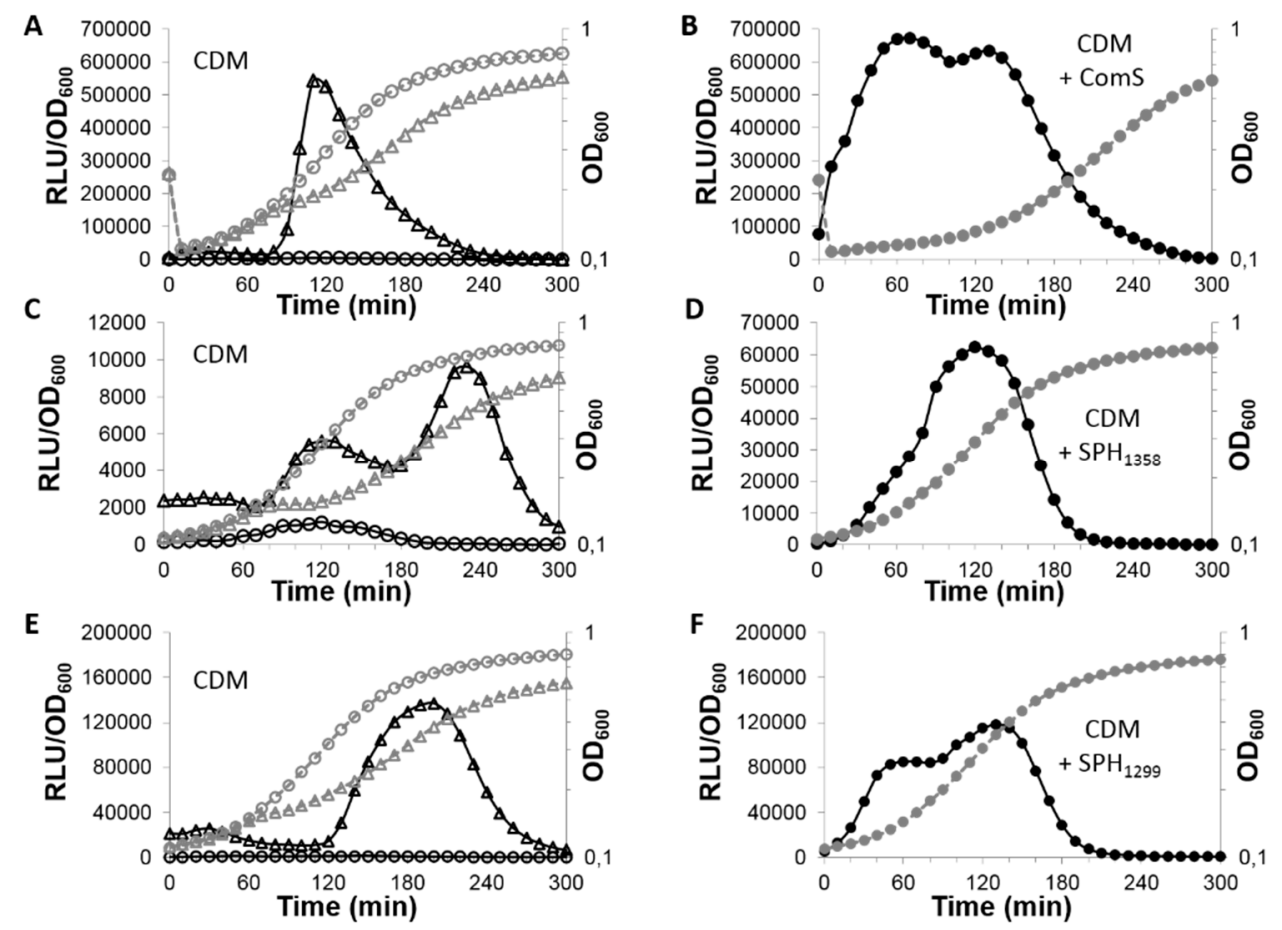

Figure 2. Growth and luciferase activity levels for strains that contained PcomX-luxAB, Pshp $1358-\operatorname{lux} A B$, or Pshp $1299-l u x A B$ fusions in a wild-type or a pptAB::erm background and grown in CDM with or without a synthetic autoinducing peptide (AIP). The growth curves $\left(\mathrm{OD}_{600}\right)$ are presented in gray dotted lines, and the relative levels of luciferase activity $\left(\mathrm{RLU} / \mathrm{OD}_{600}\right)$ in black solid lines. Results are shown for strains grown in CDM containing PcomX-luxAB (A), Pshp 1358 -luxAB (C), or Pshp $1299-l u x A B$ (E) fusions with a wild-type background $(\triangle)$ or $p p t A B$ ::erm background $(\bigcirc)$ and for strains grown in CDM with the cognate AIP stated on the figure and containing PcomX-luxAB (B), Pshp 1358 -luxAB (D), or Pshp $1299-$ lux $A B(\mathbf{F})$ fusions with a pptAB::erm background $(\bullet)$. Data shown are representative of three independent experiments.

\subsection{Total RNA Extraction}

The strains were grown in $\mathrm{CDM}$ at $42{ }^{\circ} \mathrm{C}$, and samples were taken from the cultures at the end of the exponential growth phase $\left(\mathrm{OD}_{600}=1\right)$. TIL1560, TIL1561, TIL1562, and TIL1564 were the strains used (Table 1). The cells were harvested via fast centrifugation (at 13,400 $\mathrm{g}$ for $15 \mathrm{~s}$ ); the 
supernatants were removed; and, the bacterial pellets were frozen in liquid nitrogen and stored at $-80^{\circ} \mathrm{C}$. The cells were then lysed in phenol-chloroform 5:1 $(v / v)$ with a FastPrep FT120 tissue grinder (Thermo Savant, Holbrook, NY, USA). Two cycles of cell disruption were performed (both at $6.5 \mathrm{~m} \mathrm{~s}^{-1}$ for $45 \mathrm{~s}$ ). Cellular debris was pelleted by centrifugation (at $16,000 \mathrm{~g}$ and $4{ }^{\circ} \mathrm{C}$ for $10 \mathrm{~min}$.) and the supernatants were collected. The total RNA extraction was then performed using the Direct-Zol RNA MiniPrep Kit (Zymo Research, Irvine, CA, USA) in accordance with the manufacturer's instructions. Genomic DNA was eliminated with a DNA-free DNA Removal Kit (Invitrogen, Waltham, MA, USA). Finally, RNA quantity and quality were assessed using a Qubit RNA HS Assay Kit (Thermo Fisher Scientific, USA) and a Bioanalyzer system (Agilent, Santa Clara, CA, USA), respectively. For each strain, RNA was extracted from the three biological replicates.

\subsection{RNA Sequencing and Transcriptome Analysis}

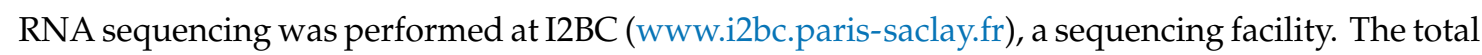
transcript libraries were created using a Stranded mRNA Library Prep Kit (Illumina). We followed the manufacturer's instructions, except in the initial steps (i.e., up until RNA fragmentation), where polyA purification was replaced by rRNA depletion using a Ribo-Zero Kit (Illumina). Quality control was carried out on the libraries using a Bioanalyzer HS DNA Kit (Agilent) and a dsDNA HS Assay Kit (Thermo Fisher Scientific, USA). The libraries were then sequenced (single-end reading, read length of $75 \mathrm{bp}$ ) using an Illumina NextSeq 500 System. The raw reads were demultiplexed, and fastq files were created from the output with bcl2fastq2 (v. 2.18.12; Illumina). The adapters were subsequently trimmed out of the reads using Cutadapt (v. 1.15; [39], and read quality was then verified via FastQC (v. 0.11.5; http://www.bioinformatics.babraham.ac.uk/projects/fastqc/). The clean reads in the total transcript libraries were then mapped against the $S$. thermophilus LMD-9 genome while using BWA-aln (v. 0.6.2-r126; [40]). The LMD-9 genome was processed beforehand using BactgeneSHOW to predict short CDSs [41,42]. We used the following option parameters: -m 4C_si -rbs $\mathrm{m} 1$-duprev -cdst 0.01 . The dataset included predicted CDSs (45-180 nt) that were not present in the GenBank annotation for LMD-9 (chromosome: CP000419.1; plasmid 1: CP000420.1; plasmid 2: CP000421.1) [34] (Supplementary Table S3). The raw read counts were calculated using the featureCounts tool (option $-\mathrm{s} 1$ ) in the SubRead package (v. 1.5.2; [43]). We employed DESeq2 (v. 1.18.1; [44]) to carry out normalization and differential analysis. First, the total read counts were normalized using the median of ratios method [45]. Subsequently, gene expression was compared between our reference strain, TIL1560

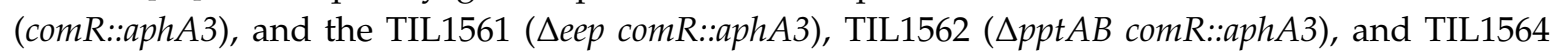
$(\triangle a m i C D E \operatorname{comR}:: a p h A 3)$ strains to examine the roles of the eep, ppt $A B$, and amiCDE genes. The resulting $p$-values were adjusted using the false discovery rate method [46]. In our further analyses, we only focused on genes with adjusted $p$-values $\leq 0.01$ and for which there was at least a 1.9-fold difference between the reference strain and the other strains. The RNA-seq raw data from this study have been deposited in the ArrayExpress database at EMBL-EBI under accession number E-MTAB-9568 (www.ebi.ac.uk/arrayexpress).

\subsection{Bioinformatic Tools}

We employed BlastP (v. 2. 9.0) with standard parameters and the PptAB proteins of S. mutans UA159 as baits to identify the PptAB homologous proteins of $S$. thermophilus LMD-9. PptA of $S$. thermophilus was found to be encoded by the Ster_RS07730 gene (previous nomenclature: Ster_1572). PptB of S. thermophilus was found to be encoded by the Ster_RS07725 gene (previous nomenclature: Ster_1571). We used the 65 complete genome sequences available in the NCBI database (https: //www.ncbi.nlm.nih.gov/genome) to compare the amino acid sequences of PptA and PptB inside the $S$. thermophilus species. 


\section{Results}

3.1. The PptAB Genes Are Expressed in S. thermophilus and Required for the Positive Control of Three Signaling Systems

PptAB is an ABC transporter that is made of a membrane-bound cytoplasmic ATP-binding protein, PptA, which provides the energy for substrate translocation, and a transmembrane protein, PptB, which forms the pore. It was first identified in E. faecalis [19]. However, shortly thereafter, orthologous genes encoding exporters with similar functions were found in S. pyogenes, S. mutans [30] and S. agalactiae [24]. We used the PptAB proteins in the S. mutans UA159 strain to identify any corresponding proteins in the S. thermophilus LMD-9 strain [47]. PptA of S. thermophilus shared 77\% identity with PptA of S. mutans (88\% sequence similarity) and PptB shared 51\% identity with PptB of S. mutans (70\% sequence similarity). The PptA and PptB proteins are highly conserved in the species S. thermophilus, estimates of shared identity range between 98 and 100 for PptA and between 97 and 100 for PptB.

First, we characterized the expression patterns of the $p p t A B$ genes in two media, CDM and M17lac, while using a $\mathrm{P}_{p p t A B}-l u x A B$ transcriptional fusion in the TIL1557 strain. We found that gene expression was constitutive throughout the exponential growth phase and it was higher in CDM than in M17lac (Figure 1). Second, we deleted the pptAB genes and characterized the phenotype of the resulting strains. To date, three RRNPP signaling systems have been studied in the LMD-9 strain of S. thermophilus. They involve three different AIPs that are potentially exported by PptAB, but only two systems have been associated with a phenotype.

The first is a SHP/Rgg system that is based on a nine-amino-acid-long hydrophobic AIP, SHP $_{1358}$ (EGIIVIVVG). This system helps to produce the streptide encoded by the Ster_RS010575 gene [27]. Therefore, we measured streptide production by the TIL1179 strain, which had a wild-type background and the TIL1565 strain, which bore the $\triangle p p t A B$ mutation using LC-MS/MS; streptide levels were quantified by measuring the integrated area under the curve in extracted-ion chromatograms for the three biological replicates per strain. The TIL1179 strain had a mean $\left( \pm\right.$ SD) streptide level of $2.7 \times 10^{8}$ $\left( \pm 4 \times 10^{7}\right)$. In contrast, the streptide level was $<7 \times 10^{4}$ in the TIL1565 strain. This result indicates that streptide was only produced at trace levels when the $p p t A B$ genes were inactivated.

The second system is based on the mature form of ComS (IAILPYFAGCL), which is also hydrophobic, but composed of eleven amino acids [28]. It controls the activity of ComR, a transcriptional regulator that is involved in mediating competence. Indeed, the ComS/ComR system positively controls the transcription of the $\operatorname{com} X$ gene. Com $X$ is an alternative sigma factor that controls the transcription of genes encoding the transformasome, a protein complex essential for competence [31,48]. Therefore, we assessed the competence of the TIL1558 strain, a $\triangle p p t A B$ mutant, when it was grown in CDM with $\mathrm{pG}^{+}$host9. No transformants were detected, which indicated that the mutant had completely lost the ability to transform naturally. However, the transformability of strain TIL1558 was restored with the addition of synthetic ComS in the CDM medium, as demonstrated with the construction of strains TIL1562, TIL1563, and TIL1565 (Table 1).

The third RRNPP system is the SHP/Rgg 1299 system. It is known to be functional, but its target function is unknown.

Thus, we wanted to demonstrate that streptide production and competence were specifically influenced by the elimination of expression of the RRNPP QS target genes in the $\triangle p p t A B$ mutant. Therefore, we quantified the expression of the comX gene, a target of the ComS/ComR system, the $\operatorname{sh} p_{1358}$ gene, a target of the SHP/Rgg 1358 system, and also the $s h p_{1299}$ gene, a target of the SHP/Rgg 1299 system. The mature form of its $\mathrm{AIP}, \mathrm{SHP}_{1299}$ (DIIIFPPFG), is similar to $\mathrm{SHP}_{1358}$ because it is also nine amino acids long and mostly hydrophobic. To this end, we used transcriptional fusions between the promoter of these three genes and the $\operatorname{lu} x A B$ genes encoding a luciferase and then explored gene expression in the wild-type versus the $p p t A B::$ erm background. In the three systems, the genes encoding the AIPs, shp genes, or com $S$ gene, are system targets, creating a positive feedback loop and resulting in the marked 
expression of all the target genes [27,31,33]. Interestingly, although the three systems function similarly because they involve the export and reimport of AIPs, the three target genes were not expressed at the same moment during strain growth (Figure 2). The comX gene and the $s h p_{1299}$ gene were expressed at the beginning and the middle of the exponential growth phase, respectively (Figure 2A,E). In contrast, the $\operatorname{sh} p_{1358}$ gene displayed a bimodal pattern during growth: there was a lower peak of expression early on and then a higher peak at the end (Figure 2C). These differences in the timing of expression indicate that, although the mechanisms that underlie each system are similar, they are not identical. In the $p p t A B:: e r m$ background, the expression of the comX and the $s h p_{1299}$ genes was completely absent (Figure 2A,E) and it dropped to trace levels for the $s h p_{1358}$ gene. In conclusion, these results show that PptAB is necessary for the expression of the three target genes and, therefore, for the functionality of the three QS systems.

We added the cognate mature AIPs ComS, $\mathrm{SHP}_{1358}$, and $\mathrm{SHP}_{1299}$ to cultures of the strains that contained the three transcriptional fusions in the $p p t A B$ ::erm background in order to verify PptAB's predicted role in AIP export. The addition of the cognate AIPs immediately triggered the expression of the $\operatorname{comX}$, or $s h p_{1299}$ genes at levels that are similar than those obtained when the $p p t A B$ genes were functional (Figure 2B,F) and at a level six times higher for the $s h p_{1358}$ gene (Figure 2D). Consequently, the functionality of the three QS systems was fully restored, confirming that PptAB plays a role in signal production, not signal detection, for these three systems. We deleted the amiCDE genes in strains TIL1488 (blp::comX-luxAB pptAB::erm), TIL1489 (blp::Pshp 1358 -luxAB pptAB::erm), and TIL1491 (blp::shp $1299-l u x A B$ pptAB::erm). Using luciferase assays, we checked that the expression of the comX, $s h p_{1358}$ and $s h p_{1299}$ genes remained absent in the presence of the cognate AIP (data not shown), which confirmed that Ami is the importer of the AIPs in strain TIL1488, TIL1489, and TIL1491.

\subsection{PptAB is Involved in the Export of $S H P_{1358}$ and $S H P_{1299}$}

To determine whether PptAB helps export the AIPs in S. thermophilus, we used LC-MS/MS to ascertain whether mature forms of $\mathrm{SHP}_{1358}$ and $\mathrm{SHP}_{1299}$ were present in the wild-type strain and absent in the $\triangle p p t A B$ mutant (TIL1558). We did not look for ComS, which is not detectable via LC-MS/MS in the supernatant of the wild-type strain [28].

As expected based on prior research, we found mature forms of $\mathrm{SHP}_{1358}$ and $\mathrm{SHP}_{1299}$ in the wild-type strain [27,33] (Figure S1) but not in the $\triangle p p t A B$ mutant. This result fits with our prior research showing that the $\operatorname{sh} p_{1358}$ and $s h p_{1299}$ genes were not expressed in the $p p t A B$ mutant due to the disruption of the positive feedback loop.

To further characterize the key role played by PptAB as a peptide exporter, we delved deeper into how the mature form of $\mathrm{SHP}_{1358}$ is produced. We uncoupled the expression of the $s h p_{1358}$ gene from the presence of PptAB by introducing the plasmid pBV5030::P32-shp 1358 into the $\Delta p p t A B$ mutant, creating the TIL1563 strain. Because of the plasmid, shp 1358 expression was under the control of a strong promoter and it was not reliant on the autoregulation loop generated by the SHP/Rgg 1358 system. As a result, there was constant independent synthesis of a $\mathrm{SHP}_{1358}$-like precursor, which, due to technical constraints, contained a glycine residue between the methionine at position 1 and the lysine at position 2 of the wild-type sequence [27]. This 24-amino-acid-long precursor (hereafter, $\mathrm{SHP}^{*}{ }_{1358}$ ) can serve as the basis for the 9-amino-acid-long mature wild-type peptide, as seen below in the results for the TIL1213 strain. We did not detect the presence of mature SHP 1358 in the TIL1563 strain, which demonstrated that the PptAB transporter is required for the peptide's production.

\subsection{PptAB Only Exports the Mature Form of $\mathrm{SHP}_{1358}$}

Past research has shown that PptAB is necessary for the production of active AIPs, but which form(s) of AIPs are recognized by PptAB? We cannot exclude the possibility that PptAB can export forms that are longer than mature AIPs, which may undergo further maturation via the action of extracellular proteases. PptAB might also be able to export the complementary sequence of the mature form of SHP* 1358 (i.e., the N-terminal peptide that results from the maturation of $\mathrm{SHP}^{*} 1358\left[\mathrm{SHP}^{*} 1358(1-15)\right]$ ) and the 
related products of degradation. Therefore, using the TIL1213 strain ( $\triangle a$ miCDE pBV5030:: $\mathrm{P}_{32}-\mathrm{sh}_{1358}$ ), we looked for traces of SHP* ${ }_{1358(1-15)}$ as well as for fragments that result from shortening at the

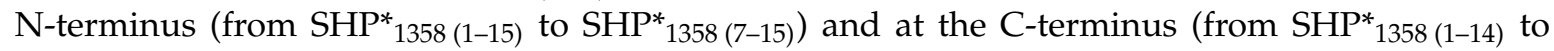
SHP $^{*} 1358$ (1-10) $)$ (Table S4). The TIL1213 strain might have accumulated these peptides, since it was able to synthesize the AIP precursor thanks to the presence of the plasmid pBV5030:: $\mathrm{P}_{32}-\mathrm{sh}_{1358}$; however, the strain was unable to reimport any peptides because the Ami importer was inactivated. While we confirmed the presence of mature $\mathrm{SHP}_{1358}$ in the supernatant, we found no evidence of the fragments (data not shown). These results indicate that the precursor is likely matured in either the cytoplasm or in the cell membrane prior to secretion and that PptAB only interacts with the peptide's mature form.

\subsection{PptAB Controls Transcription of the Genes Located Downstream from the Rgg Genes in S. thermophilus}

Because PptAB helps export the AIPs that control the activity of transcriptional regulators, we used a deep sequencing approach (RNAseq) to identify all of the genes whose expression is controlled by PptAB. The genome of LMD-9 contains three complete shp/rgg loci in addition to the $\mathrm{sh} / \mathrm{rgg} 1358$ and shp/rgg 1299 loci, as well as a locus with truncated $\operatorname{sh} p$ and $r g g$ genes (sCDS_305/Ster_RS03240) (Figure S2A). Thus, we hypothesized that other genes in the near or far vicinity of the rgg genes could also be controlled by this transporter. The ComR regulon, partially controlled by PptAB through the export of the mature form of its cognate AIP ComS, was previously identified in S. thermophilus $[26,48]$. Because the regulon encompasses more than 100 genes, we chose to work in a $\Delta c o m R$ background, so that we could identify PptAB regulon in the absence of the genes that are regulated by the ComS/ComR system. Therefore, we compared gene expression between the TIL1560 (comR::aphA3) and TIL1562 (comR::aphA3 $\triangle p p t A B$ ) strains. The $s h p_{1299}$ and $s h p_{1358}$ genes, the two distinct targets of the SHP/Rgg systems, were highly expressed at the end of the exponential growth phase (Figure 1), so samples for mRNA extraction were obtained at this stage $\left(\mathrm{OD}_{600}=1\right)$. Genes were upregulated in the TIL1520 strain compared to in the TIL1562 strain (Table 2; Figure 3). Except sCDS_305/Ster_RS03240 locus (Figure S2A), the expression of all genes located downstream of the other five rgg genes and some, but not all of their cognate shp genes were controlled by PptAB. Hereafter, these genes will be referred as the proximal target genes of the Rgg regulators. We discovered two distal target genes (i.e., not located near a shp/rgg locus) that were regulated by PptAB: one short CDS (CDS_560) that was poorly expressed and one operon (Ster_RS04380-90). The short CDS has an unknown function, and the operon contains genes that are annotated as encoding enzymes that are involved in cysteine metabolism. 
Table 2. Genes significantly upregulated in the TIL1560 strain (comR::aphA3) versus in the TIL1562 strain (comR::aphA3 $\Delta$ pptAB) (positively controlled by PptAB).

\begin{tabular}{|c|c|c|c|c|c|c|c|c|c|c|}
\hline Locus Tag & $\begin{array}{c}\text { Old Locus } \\
\text { Tag }\end{array}$ & $\begin{array}{c}\text { Fold } \\
\text { Change }\end{array}$ & TIL1560* & TIL1562 * & Start & Stop & Strand & Gene Name & $\begin{array}{l}\text { Protein } \\
\text { Length }\end{array}$ & Description \\
\hline \multicolumn{11}{|c|}{ Cluster STER_RS04380-STER_RS04390 } \\
\hline STER_RS04380 & STER_0885 & 3.6 & 2552 & 704 & 817570 & 818481 & + & & 303 & \multirow{3}{*}{$\begin{array}{l}\text { cysteine synthase family } \\
\text { protein } \\
\text { aminotransferase class V-fold } \\
\text { PLP-dependent enzyme } \\
\text { serine acetyltransferase }\end{array}$} \\
\hline STER_RS04385 & STER_0886 & 3.8 & 3818 & 1006 & 818503 & 819687 & + & & 394 & \\
\hline STER_RS04390 & STER_0887 & 3.9 & 1704 & 433 & 819629 & 820210 & + & & 193 & \\
\hline \multicolumn{11}{|c|}{ Locus sCDS_265/Ster_RS04620 } \\
\hline STER_SCDS_265 & STER_0933 & NR & 20 & 7 & 864863 & 864934 & - & $\operatorname{sh} p_{265}$ & 23 & \multirow{5}{*}{$\begin{array}{c}\text { MutR family transcriptional } \\
\text { regulator } \\
\text { Fe-S oxidoreductase }\end{array}$} \\
\hline STER_RS04620 & STER_0934 & NR & 1214 & 1296 & 865021 & 865878 & + & $r g g_{4620}$ & 285 & \\
\hline STER_RS04625 & STER_0935 & 3.0 & 3966 & 1322 & 865938 & 866738 & + & & 266 & \\
\hline STER_SCDS_510 & & 3.8 & 990 & 259 & 866798 & 866947 & + & & 49 & \\
\hline STER_SCDS_661 & & 2.5 & 351 & 141 & 867030 & 867119 & + & & 29 & \\
\hline STER_RS04630 & STER_0937 & 2.7 & 3087 & 1132 & 867149 & 868246 & + & & 365 & \multirow{3}{*}{$\begin{array}{l}\text { radical SAM protein } \\
\text { arginase family protein } \\
\text { MFS transporter }\end{array}$} \\
\hline STER_RS04635 & STER_0938 & 2.8 & 1748 & 629 & 868243 & 868986 & + & & 247 & \\
\hline STER_RS04640 & STER_0939 & 2.2 & 3534 & 1641 & 868993 & 870165 & + & & 390 & \\
\hline \multicolumn{11}{|c|}{ Locus shp/rgg 1299} \\
\hline STER_RS06360 & STER_1290 & 2.0 & 601 & 296 & 1198824 & 1199426 & - & rr06 & 200 & \multirow{13}{*}{$\begin{array}{c}\text { response regulator } \\
\text { transcription factor } \\
\text { sensor histidine kinase } \\
\text { ABC transporter permease } \\
\text { MULTISPECIES: ABC } \\
\text { transporter ATP-binding } \\
\text { protein } \\
\text { hypothetical protein } \\
\text { hypothetical protein } \\
\text { hypothetical protein } \\
\text { (incomplete) } \\
\text { hypothetical protein } \\
\text { (incomplete) } \\
\text { MFS transporter permease } \\
\text { oligoendopeptidase F }\end{array}$} \\
\hline STER_RS06365 & STER_1291 & 1.9 & 1125 & 593 & 1199423 & 1200517 & - & $h k 06$ & 364 & \\
\hline STER_RS06370 & STER_1292 & 11.2 & 504 & 45 & 1200510 & 1201247 & - & & 245 & \\
\hline STER_RS06375 & STER_1293 & 12.8 & 545 & 43 & 1201244 & 1202125 & - & & 293 & \\
\hline STER_RS06380 & STER_1294 & 13.3 & 111 & 8 & 1202118 & 1202297 & - & & 59 & \\
\hline STER_RS06385 & STER_1295 & 18.7 & 183 & 10 & 1202308 & 1202517 & - & & 69 & \\
\hline STER_RS06390 & & ND & ND & ND & 1202668 & 1202934 & - & & 87 & \\
\hline STER_RS10535 & & ND & ND & ND & 1202925 & 1203152 & - & & 74 & \\
\hline STER_sCDS_172 & & 56.6 & 8877 & 157 & 1203195 & 1203290 & - & & 31 & \\
\hline STER_RS06395 & STER_1296 & 59.7 & 93273 & 1563 & 1203277 & 1204506 & - & & 409 & \\
\hline STER_RS06400 & STER_1297 & 49.7 & 195871 & 3942 & 1204484 & 1206817 & - & & 777 & \\
\hline STER_SCDS_398 & & 46.3 & 97 & 2 & 1206867 & 1206920 & - & & 17 & \\
\hline STER_sCDS_310 & & NR & 1 & 1 & 1206895 & 1206960 & - & & 21 & \\
\hline
\end{tabular}


Table 2. Cont.

\begin{tabular}{|c|c|c|c|c|c|c|c|c|c|c|}
\hline Locus Tag & $\begin{array}{l}\text { Old Locus } \\
\text { Tag }\end{array}$ & $\begin{array}{l}\text { Fold } \\
\text { Change }\end{array}$ & TIL1560* & TIL1562 * & Start & Stop & Strand & Gene Name & $\begin{array}{l}\text { Protein } \\
\text { Length }\end{array}$ & Description \\
\hline STER_sCDS_714 & STER_1298 & 67.4 & 1015 & 15 & 1207133 & 1207213 & + & shp1299 & 26 & \multirow[b]{2}{*}{$\begin{array}{l}\text { XRE family transcriptional } \\
\text { regulator }\end{array}$} \\
\hline STER_RS06405 & STER_1299 & NR & 924 & 1060 & 1207191 & 1208066 & - & rgg1299 & 291 & \\
\hline \multicolumn{11}{|l|}{ Locus $\mathrm{shp} / \mathrm{rgg}_{1358}$} \\
\hline STER_sCDS_566 & & 9.8 & 76 & 8 & 1255722 & 1255835 & + & & 37 & \multirow{8}{*}{$\begin{array}{l}\text { hypothetical protein } \\
\text { hypothetical protein } \\
\text { sodium transporter } \\
\text { hypothetical protein } \\
\text { (incomplete) }\end{array}$} \\
\hline STER_sCDS_613 & & NR & 25 & 31 & 1256064 & 1256165 & + & & 33 & \\
\hline STER_sCDS_543 & & NR & 26 & 14 & 1256228 & 1256353 & + & & 41 & \\
\hline STER_sCDS_851 & & NR & 0 & 0 & 1256331 & 1256390 & + & & 19 & \\
\hline STER_RS06660 & STER_1350 & 3.1 & 137 & 44 & 1256335 & 1256604 & + & & 89 & \\
\hline STER_RS06665 & STER_1351 & NR & 55 & 70 & 1256764 & 1257063 & + & & 99 & \\
\hline STER_RS06670 & STER_1352 & 114.6 & 32175 & 281 & 1257163 & 1258074 & - & & 303 & \\
\hline STER_RS06675 & & ND & ND & ND & 1258071 & 1258393 & - & & 107 & \\
\hline STER_RS06680 & & 132.9 & 21819 & 164 & 1258390 & 1258992 & - & & 200 & \multirow{6}{*}{$\begin{array}{l}\text { protein } \\
\text { MULTISPECIES: transporter } \\
\text { KxxxW cyclic peptide radical } \\
\text { SAM maturase } \\
\text { KxxxW-cyclized peptide } \\
\text { pheromone } \\
\text { MutR family transcriptional } \\
\text { regulator }\end{array}$} \\
\hline STER_RS06685 & STER_1355 & 113.3 & 31202 & 275 & 1259086 & 1260177 & - & $\operatorname{str} C$ & 363 & \\
\hline STER_RS06690 & STER_1356 & 109.6 & 53740 & 490 & 1260174 & 1261493 & - & $\operatorname{str} B$ & 439 & \\
\hline STER_RS10575 & STER_1357 & 78.0 & 6544 & 84 & 1261563 & 1261655 & - & $\operatorname{str} A$ & 30 & \\
\hline STER_RS06695 & STER_1358 & NR & 450 & 565 & 1261738 & 1262598 & - & $\operatorname{rgg} 1358$ & 286 & \\
\hline STER_sCDS_768 & & 114.8 & 723 & 6 & 1262689 & 1262760 & + & $\operatorname{shp} 1358$ & 23 & \\
\hline \multicolumn{11}{|c|}{ Locus sCDS_273/Ster_RS07530 } \\
\hline STER_sCDS_273 & & NR & 3 & 8 & 1434537 & 1434608 & - & $\operatorname{sh} p_{273}$ & 23 & \multirow{3}{*}{$\begin{array}{c}\text { MutR family transcriptional } \\
\text { regulator } \\
\text { MFS transporter }\end{array}$} \\
\hline STER_RS07530 & STER_1530 & NR & 648 & 628 & 1434695 & 1435558 & + & $\operatorname{rgg}_{7530}$ & 287 & \\
\hline STER_RS07535 & STER_1531 & 28.9 & 19052 & 660 & 1435675 & 1436853 & + & & 392 & \\
\hline \multicolumn{11}{|c|}{ Gene STER_sCDS_560 } \\
\hline STER_sCDS_560 & & 3.2 & 39 & 12 & 1441243 & 1441359 & + & & 38 & \\
\hline \multicolumn{11}{|l|}{ pptAB } \\
\hline STER_RS07725 & STER_1571 & 37.9 & 5837 & 154 & 1472993 & 1474030 & - & $p p t B$ & 345 & \multirow{2}{*}{$\begin{array}{c}\mathrm{ABC} \text { transporter permease } \\
\mathrm{ABC} \text { transporter ATP-binding } \\
\text { protein }\end{array}$} \\
\hline STER_RS07730 & STER_1572 & 2491 & 3491 & 1 & 1474027 & 1474758 & - & $p p t A$ & 243 & \\
\hline
\end{tabular}


Table 2. Cont

\begin{tabular}{|c|c|c|c|c|c|c|c|c|c|c|}
\hline Locus Tag & $\begin{array}{l}\text { Old Locus } \\
\text { Tag }\end{array}$ & $\begin{array}{c}\text { Fold } \\
\text { Change }\end{array}$ & TIL1560* & TIL1562* & Start & Stop & Strand & Gene Name & $\begin{array}{l}\text { Protein } \\
\text { Length }\end{array}$ & Description \\
\hline \multicolumn{11}{|c|}{ Locus sCDS_279/Ster_RS09420 } \\
\hline STER_sCDS_279 & & 1.9 & 139 & 74 & 1785690 & 1785761 & - & $s h p_{279}$ & 23 & \multirow{5}{*}{$\begin{array}{l}\text { MutR family transcriptional } \\
\text { regulator }\end{array}$} \\
\hline STER_RS09420 & & NR & 1102 & 1194 & 1786014 & 1786712 & + & $r g g_{9420}$ & 232 & \\
\hline STER_sCDS_584 & & NR & 71 & 92 & 1786790 & 1786897 & + & & 35 & \\
\hline STER_sCDS_809 & & NR & 0 & 0 & 1786854 & 1786919 & + & & 21 & \\
\hline STER_sCDS_462 & & 13.1 & 1242 & 95 & 1786909 & 1787088 & + & & 59 & \\
\hline STER_RS09425 & STER_1924 & 14.9 & 15002 & 1007 & 1787097 & 1788152 & + & & 351 & \multirow{3}{*}{$\begin{array}{c}\text { radical SAM protein } \\
\text { ABC transporter ATP-binding } \\
\text { protein }\end{array}$} \\
\hline STER_RS09430 & STER_1925 & 15.4 & 18315 & 1192 & 1788145 & 1789686 & + & & 513 & \\
\hline STER_sCDS_680 & & 19.6 & 150 & 8 & 1789819 & 1789905 & + & & 28 & \\
\hline
\end{tabular}

Only genes with an adjusted $p$-value $\leq 0.01$ and an at least 1.9-fold change were examined; NR, not significantly regulated (adjusted $p$-value $>0.01$ ); ND, not determined; ${ }^{*}$ Average of normalized read counts from the three biological replicates. 


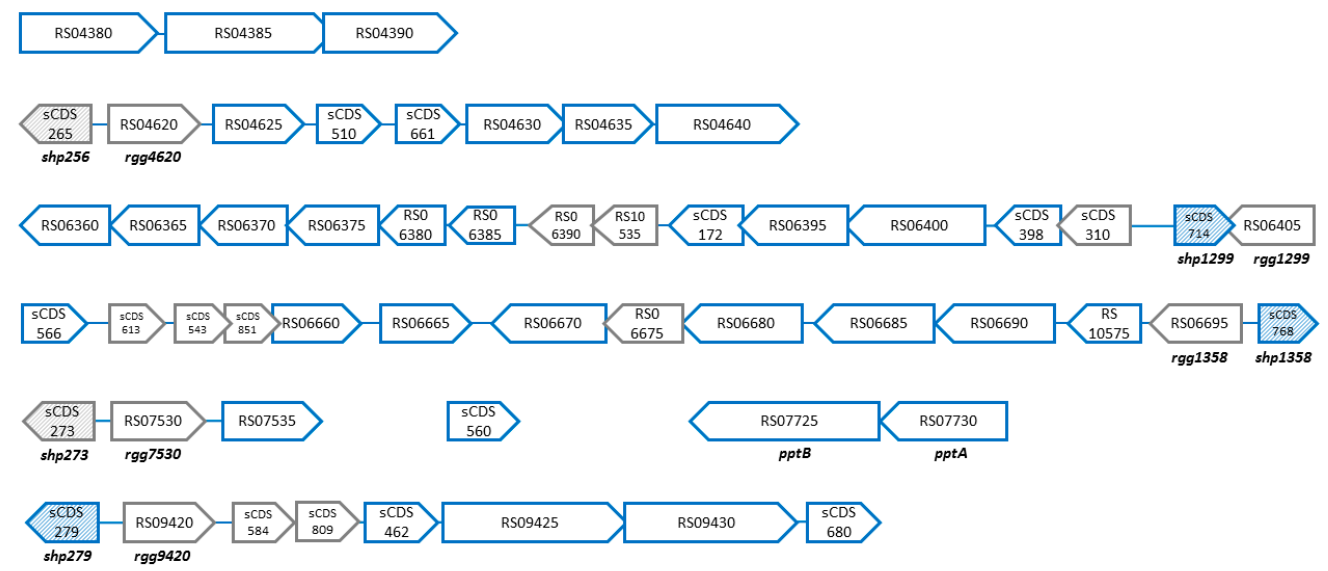

Figure 3. Organizational schematic of the genes controlled by PptAB. The genes whose expression was upregulated in the TIL1560 strain (comR::aphA3) compared to the TIL1562 strain (comR::aphA3 $\triangle p p t A B)$ are shown in blue. This set of genes was controlled by PptAB but did not include genes regulated by ComR, which controls competence. ORF orientation within each cluster is indicated by the direction of the arrowhead (not to scale). Genes encoding SHPs have hatched shading. Genes that were not regulated by PptAB are in gray. Genes were named and described in accordance with their GenBank annotations, to which we added in-lab annotations for the short genes (see the Materials and methods section and Table S3).

We could distinguish three classes of genes located downstream from the rgg genes. First, there were two sets of highly expressed genes (based on the average of the normalized read counts) located downstream from the two $r g g$ genes already studied, $r g g_{1299}$ and $r g g_{1358}$; they were strongly controlled by PptAB and displayed greater than 45 -fold changes in expression (Table 2). The genes downstream from the $\mathrm{rgg}_{1299}$ gene were all transcribed in the same direction, but, the greater their proximity, the higher their level of transcription and fold change. The operon's initial genes encode an enzyme (annotated oligopeptidase F), a transporter, and a peptide. The function of these genes is unknown. The operon's later genes encode two peptides, an ABC transporter, and a two-component system whose function seems to be linked to rhamnose-glucose polysaccharide synthesis induced by bacitracin stress [49]. The genes downstream from $\mathrm{rgg}_{1358}$ form two transcriptional units. The first unit was transcribed in the same direction as $r g g_{1358}$ and it was strongly controlled by PptAB; it encodes proteins that are involved in the production of the streptide [20,32] and two additional proteins with unknown functions. The second unit was transcribed in the opposite direction and it was weakly controlled by PptAB; it encodes peptides or small proteins with unknown functions. The transcription of the two shp genes at these loci was also strongly controlled by PptAB, as had already been demonstrated via the transcriptional fusions with the luciferase reporter (Figure 2).

The second class of genes involved two shp/rgg loci, sCDS_273/Ster_RS07530 and sCDS_279/Ster_RS09420. For this gene class, gene expression was relatively high in the TIL1560 strain, with fold changes ranging between 13 and 29. The shp gene at the sCDS_273/Ster_RS07530 locus was not expressed. The shp gene at the sCDS_279/Ster_RS09420 locus was weakly expressed and weakly controlled by PptAB (1.9-fold change). The sole proximal target gene in the sCDS_273/Ster_RS07530 system encodes a transporter with an unknown function. The proximal target genes in the sCDS_279/Ster_RS09420 system are similar to those at the streptide locus, with a gene encoding a SAM radical enzyme, a gene encoding a transporter, and two genes encoding peptides with unknown functions. The third class of genes was associated with the locus sCDS_265/Ster_RS04620. The genes were weakly expressed and controlled by PptAB (three-fold change). The shp gene at this locus was not expressed. Again, the proximal target genes were similar to those at the streptide locus, with a gene encoding a SAM radical enzyme, a gene encoding a transporter, two genes encoding peptides, a gene encoding an Fe-S oxido-reductase, and a gene encoding an arginase. 
We found very similar expression levels and fold changes when we compared gene expression

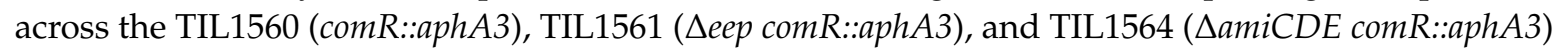
strains (Tables S5 and S6). The differences mainly involved short CDSs encoding genes that were poorly expressed and for which regulation resulted in a three-fold change at most (sCDS_180, sCDS_560, sCDS_279, and sCDS_854). Only one gene (Ster_RS06940) was found to be downregulated in the eep mutant (Table S5); it encodes a peptide-binding protein of the Ami transporter and it was expressed at high levels in the TIL1560 strain. The expression of this gene was unaffected by the amiCDE and $p p t A B$ mutations. We also found that one gene (Ster_RS09420) was upregulated 1.9 fold in the amiCDE mutant, but it was poorly expressed in general (data not shown). Furthermore, it is important to note that none of the genes in plasmid 1 were expressed in the TIL1561 strain. Upon PCR verification, we discovered that this strain had lost this plasmid during the construction process (data not shown).

Finally, we observed that the $s h p_{279}$ gene was expressed at very low levels. As a result, we questioned whether the expression levels were sufficient to allow for the production of mature $\mathrm{SHP}_{279}$ in the wild-type strain. We found that the mature form of $\mathrm{SHP}_{279}$ was indeed present in the wild-type strain (Figure S3) as well as in the TIL883 strain ( $\triangle a m i C D E$ ) (data not shown). Interestingly, it was absent in the TIL773 ( $\triangle e e p)$ and TIL1558 ( $\triangle p p t A B)$ strains.

\section{Discussion}

PptAB has been identified as the exporter of the pheromones of PrgX in E. faecalis [19] and of Rgg and ComR in pathogenic streptococci S. pyogenes, S. mutans [30] and S. agalactiae, [24]. PptAB also exports peptides in $S$. aureus via a mechanism that is similar to the one that produces the pheromones in E. faecalis. However, the biological function of these peptides remains unclear [50,51]. The role of PptAB in the starter species $S$. thermophilus had previously remained unexplored, even though this bacterium has a comS/comR locus and it is one of the streptococcus species with S. pneumoniae with the greatest number of paralogous shp/rgg loci. In this study, we used genetic approaches and mass spectrometry to show that PptAB can export the mature AIPs of four different systems: ComS/ComR, SHP/Rgg 299 , $\mathrm{SHP} / \mathrm{Rgg}_{1358}$, and SHP/Rgg 9420 . Focusing on the SHP/Rgg 1358 system, we found direct evidence, namely the presence of mature $\mathrm{SHP}_{1358}$, that PptAB acts as a peptide exporter of this specific peptide.

Here, we studied the mature forms of AIPs in S. thermophilus. These peptides are hydrophobic and short in length, ranging in size from mime amino acids (the SHPs) to 11 amino acids (the mature ComS). These characteristics are shared by PptAB-transported AIPs in other streptococci. In the wild-type strain, we found no traces of the complementary part of mature $\mathrm{SHP}_{1358}$, a short hydrophobic peptide (14 amino acids long) that should be released after the cleavage of the precursor; we also did not observe any fragments of this complementary part. This result raised questions regarding the specificity of the transporter. One hypothesis is that PptAB only exports mature $\mathrm{SHP}_{1358}$ because its activity focuses on mature AIPs. Another hypothesis is that there is interplay between PptAB and the protease Eep, which is known to be involved in the maturation of these peptides [21,24,27]. Eep is a transmembrane zinc-metalloprotease whose active cleavage site is thought to occur in a transmembrane domain [52]. It is possible that only mature SHPs are directly delivered to PptAB. If such is the case, the fate of the complementary part remains unknown.

Most commonly, AIPs of Gram-positive bacteria are exported either by the general Sec-dependent pathway or by dedicated peptidase-containing ABC transporters that can export and mature double glycine signaling peptides, which play a role in competence or provide competitive fitness advantages in complex environments $[26,53,54]$. The PptAB export mechanism represents an intermediate solution that is neither highly generalized nor highly specific. Further research should explore the potential evolutionary benefits of this solution and, more importantly, assess whether it is a point of control in QS systems. While the expression of the $p p t A B$ genes seems constitutive, more work is needed to determine whether PptAB activity is somehow regulated.

The RNAseq approach was used to identify the genes whose expression was controlled by PptAB, Eep, and AmiCDEF. All of the genes located downstream from the five non truncated $r g g$ gene are part 
of the targets genes. Our findings suggest that non-truncated shp/rgg loci are functional and involved in the actions taken by PptAB, Eep, and AmiCDEF to regulate these target genes. Nevertheless, further work is needed in order to confirm that the expression of these target genes is indeed controlled by their cognate $r g g$ gene. These target genes were generally expressed and regulated at similar levels by the three proteins PptAB, Eep, and AmiCDEF, indicating that these target genes might belong to a single transcriptional unit. There were a few exceptions: for example, when the proximal targets of SHP/Rgg 1299 were examined, the genes farthest from the rgg gene (Ster_RS06385- Ster_RS06360) were poorly expressed and regulated. However, this effect may have resulted from readthrough transcription dynamics, rather than from issues with QS regulation. Surprisingly, these genes are also part of the ComR regulon [26]. Although some of these loci had been previously studied, using the RNAseq approach, we were able to identify additional proximal targets, such as Ster_RS06680 and Ster_RS06670 for the $\operatorname{sh} / \mathrm{rgg} 1358$ locus, and Ster_sCDS172 for the $\operatorname{sh} / \mathrm{rgg} 1299$ locus. Ster_RS06680 and Ster_RS06670 have been annotated as SPASM-domain-containing protein and sodium transporters, respectively. Here, we discovered that they belong to the str operon, but further work is needed in order to clarify their role in streptide production. The function of Ster_sCDS172 is also unknown. We additionally found significantly expressed distal target genes with a three-gene operon linked to cysteine synthesis. Research is currently underway to identify the SHP/Rgg system that is associated with this operon and to confirm the operon's function. To our knowledge, it is one of the few distal target gene of a SHP/Rgg system identified to date, although we must still verify that transcriptional control is direct. Indeed, few RNAseq approaches have been developed to exhaustively identify $\mathrm{SHP} /$ Rgg system targets in streptococci. These experiments highlighted genes located near the rgg genes in Streptococcus mitis [55], Streptococcus pneumoniae [23], or S. pyogenes [21].

The identity and expression patterns of those genes regulated by PptAB, Eep, and Ami were strikingly similar. This finding indicates that an equivalent role is being played in export, maturation, and reimport. It is highly likely that the deletion of these genes would completely inactivate the mechanism in action, leading to similar results for target gene transcription. However, a closer look at the expression of the shp genes in the wild-type strain versus the $\triangle p p t A B, \triangle e e p$, and $\triangle a m i C D E$ background revealed the existence of three different regulation scenarios.

First, the $\operatorname{sh} p_{1299}$ and $\operatorname{sh} p_{1358}$ genes were expressed at high levels, and their expression was clearly controlled by the three proteins. The result was a positive feedback loop and marked expression of the proximal target genes at the end of the exponential growth phase in the wild-type strain background. These results correspond to a scenario, in which SHP is exported by PptAB, matured by Eep, and reimported by Ami. Consequently, the activity of the associated Rgg regulator is controlled, and there is the transcription of the genes located downstream from the $r g g$ gene.

Second, the $\operatorname{shp}_{273}$ and $s h p_{265}$ genes were not expressed. This result suggests that a SHP encoded by another locus controls the activity of $\operatorname{Rgg}_{7530}$ and $\operatorname{Rgg}_{4620}$. We feel that there is more support for this hypothesis than for a hypothesis that involves the involvement of a non-cognate SHP/Rgg complex, because all of the $r g g$ genes in the wild-type strain were expressed at similar levels indicating that the genes are likely functional also this deserves further validation. The proximal target gene in the $\mathrm{SHP}_{273} / \mathrm{Rgg}_{7530}$ system was expressed at high levels and regulated by PptAB, Eep, and Ami, whereas the proximal target genes of $\mathrm{SHP}_{265} / \mathrm{Rgg}_{4620}$ were expressed at lower levels and subject to less regulation by the three proteins. Interestingly, $\mathrm{SHP}_{273}$ is nearly identical to $\mathrm{SHP}_{1358}$ : there is a single amino acid difference, a spot occupied by a valine in $\mathrm{SHP}_{1358}$ is occupied by a leucine in $\mathrm{SHP}_{273}$. $\mathrm{SHP}_{265}$ and $\mathrm{SHP}_{1358}$ differ by two amino acids: spots occupied by a glycine and a leucine in $\mathrm{SHP}_{1358}$ are occupied by a serine and an alanine, respectively, in $\mathrm{SHP}_{265}$ (Figure S2B). This finding suggests that $\mathrm{SHP}_{1358}$ is a good candidate for interacting with $\mathrm{Rgg}_{7530}$ and $\mathrm{Rgg}_{4620}$, and it could more effectively cross-activate $\operatorname{Rgg}_{7530}$, but less effectively cross-activate $\operatorname{Rgg}_{4620}$, if we assume that the cognate SHP of a Rgg is likely to be the most efficient SHP. Further experimental work is needed in order to confirm that $\mathrm{SHP}_{1358}$ can interact with different Rggs. 
Third, the gene encoding $\mathrm{SHP}_{279}$ was poorly expressed and controlled by PptAB, Eep, and Ami, but the mature form of $\mathrm{SHP}_{279}$ was present in the wild-type strain background. In contrast, the system's proximal target genes were expressed at higher levels and more strongly regulated by these three proteins than the $s h p_{279}$ gene. The Rgg regulator that was encoded by Ster_RS09420 plays a role in oxidative stress defense in the $S$. thermophilus CNRZ368 strain [56]. This system did not display a positive feedback loop related to $s h p_{279}$ expression, providing an additional element of support for the hypothesis that another SHP might interact with the $\mathrm{Rgg}_{9420}$ regulator. $\mathrm{SHP}_{279}$ is nearly identical to $\mathrm{SHP}_{1358}$ : a spot that is occupied by a valine in $\mathrm{SHP}_{1358}$ is occupied by a glycine in $\mathrm{SHP}_{279}$. Consequently, SHP1358 is again a good candidate for Rgg $_{9420}$ activation.

In a previous study, we demonstrated the absence of cross-activation between the $\mathrm{SHP}_{1299} / \mathrm{Rgg}_{1299}$ and $\mathrm{SHP}_{1358} / \operatorname{Rgg}_{1358}$ systems [33]. This result was expected, since the amino acid sequences of the two SHPs are not similar. Our findings here suggest that some SHP/Rgg systems can cross-activate each other, likely via highly similar SHPs, although this hypothesis must be experimentally tested. However, the fact that some SHP/Rgg loci encoded shp genes that were not expressed and that appeared to be activated by SHPs from other systems was surprising. Therefore, we wonder if, in S. thermophilus, these accumulated SHP/Rgg systems have degenerated or if they may prove to be useful under certain natural conditions. We also cannot exclude the possibility that other growth conditions exist, in which these shp genes are efficiently expressed. Previous work has shown that intracellular cross-activation involving $2 \mathrm{SHP} / \mathrm{Rgg}$ systems exists in S. pneumoniae [25] and in S. pyogenes [21]. However, circumstances are slightly different in the latter case because the two SHPs can interact with two Rggs with relatively similar affinities [57], although one Rgg activates transcription whereas the other inhibits it [21]. Another level of complexity is present if we consider interspecies crosstalk. This cross-talk can occur between streptococci species via SHP/Rgg systems, as demonstrated between S. pneumoniae and S. mitis [55], but also between distinct species via another RRNPP mechanism between S. aureus and E. faecalis. S. aureus can produce at least four linear peptides during the maturation process of secretion signal peptides of lipoproteins; one of these peptides can mimic a pheromone of E. faecalis and cause aggregation, the first step in horizontal gene transfer in this species [50]. Interestingly, in S. aureus, the transporter EcsAB, encoded by paralogs of the genes that encode PptAB and Eep, are necessary for the production of these peptides $[50,51]$.

\section{Conclusions}

In conclusion, in S. thermophilus, PptAB plays a central role in the export of the AIPs that are involved in intracellular QS mechanisms. A RNAseq approach designed to identify the genes regulated by the exporter PptAB, the protease Eep and the importer Ami highlighted cross-talk between SHP/Rgg systems. More work is needed now in order to dissect this crosstalk at the strain level, but also at intraan inter-species levels and to understand their various roles in natural and complex environments.

Supplementary Materials: The following are available online at http://www.mdpi.com/2073-4425/11/9/1096/s1, Table S1: Oligonucleotides used in this study, Table S2: Plasmids used in this study, Table S3: List of CDSs annotated in GenBank and short putative CDSs predicted by BactgeneSHOW in the chromosome and the two plasmids of the S. thermophilus wild-type strain (LMD-9), Table S4: List of the SHP*1358 (MGKKQILLTLLLVVFEGIIVIVVG) fragments whose masses was looked for in the TIL1213 strain ( $\triangle$ amiCDE pBV5030::P 32 -shp 1358 ) via LC-MS/MS., Table S5: Genes significantly upregulated in the TIL1560 strain (comR::aphA3) versus in the TIL1561 strain (comR::aphA3 $\triangle e e p$ ) (positively controlled by Eep), Table S6: Genes significantly upregulated in the TIL1560 strain (comR::aphA3)versus in the TIL1564 strain (comR::aphA3 $\triangle a m i C D E)$ (positively controlled by Ami), Figure S1: Detection of the mature forms of $\mathrm{SHP}_{1299}$ and $\mathrm{SHP}_{1358}$ in cultures of the S. thermophilus wild-type strain (LMD-9) via LC-MS/MS. Fragmentation spectra for $\mathrm{SHP}_{1299}(\mathrm{~A})$ and $\mathrm{SHP}_{1358}$ (B); mass, retention time, and the integrated area under the curve obtained from the extracted-ion chromatograms for both peptides $(\mathrm{C})$. The data shown are representative of three independent experiments, Figure S2: Information on the shp/rgg loci in the S. thermophilus wild-type strain (LMD-9). (A) Schematic representation of the six shp/rgg loci based on genome annotation for the LMD-9 strain, as described in Table S4. Annotations for the rgg genes come from GenBank (CP000419.1), and annotations for the shp genes were developed in our lab using BactogeneSHOW, as described in the Materials and methods section. The $r g g$ genes and shp genes are represented by black and gray arrows, respectively. The size of the protein encoded by each gene is indicated underneath. (B) Alignment of the sequences for the SHP precursors. The predicted or experimentally validated sequences for the mature forms are in bold, 
Figure S3: Detection of the mature form of $\mathrm{SHP}_{279}$ in cultures of the S. thermophilus wild-type strain (LMD-9) via LC-MS/MS. Fragmentation spectra for $\mathrm{SHP}_{279}(\mathrm{~A})$; mass, retention time, and the integrated area under the curve obtained from the extracted-ion chromatograms for the peptide (B). The data shown are representative of three independent experiments.

Author Contributions: Conceptualization, A.L., V.M., V.J. and R.J.; Formal analysis, A.L. and R.G.; Funding acquisition, V.M. and V.J.; Investigation, A.L. and C.M.; Methodology, C.M., C.H. and R.G.; Project administration, R.G.; Resources, Céline Henry; Supervision, R.G.; Validation, A.L.; Visualization, R.G.; Writing—original draft, A.L., V.M., V.J. and R.G.; Writing—review \& editing, V.M., V.J. and R.G. All authors have read and agreed to the published version of the manuscript.

Funding: This study was funded by the French National Institute for Agriculture, Food, and Environment (INRAE) and the French Ministry of Higher Education, Research, and Innovation (MESRI). Proteomics analyses were performed by the PAPPSO platform (http://pappso.inra.fr), which is supported by INRAE, the Regional Council of Ile-de-France, IBiSA, and CNRS.

Acknowledgments: We thank Lydie Oliveira-Correia for her help with the LC-MS/MS analysis. We are grateful to Françoise Rul for critical reading of the manuscript and to Jessica Pearce-Duvet for the English-language editing.

Conflicts of Interest: The authors declare that they have no known competing financial interests or personal relationships that could have appeared to influence the work reported in this paper.Abbreviations: ABC, ATP binding cassette; AIP, auto-inducing peptide; bp, base pair; CDM, chemically defined medium; CDS, coding sequence; CID, collision-induced dissociation; Erm, erythromycin; LC-MS/MS, liquid chromatography-tandem mass spectrometry; Da, Dalton; ds, double strand(ed); Km, kanamycin; OD, optical density; QS, quorum sensing; RLU, relative light units; rRNA, ribosomal RNA; RRNPP, Rap Rgg NprR PlcR PrgX; SHP, short hydrophobic peptides; XIC, ion current signal; XIP, sigX-inducing peptide.

\section{References}

1. Nealson, K.H. On the 50th Anniversary of the discovery of autoinduction and the ensuing birth of quorum sensing. Environ. Microbiol. 2020, 22, 801-807. [CrossRef]

2. Verma, S.C.; Miyashiro, T. Quorum sensing in the squid-Vibrio symbiosis. Int. J. Mol. Sci. 2013, 14, 16386-16401. [CrossRef]

3. Fontaine, L.; Wahl, A.; Fléchard, M.; Mignolet, J.; Hols, P. Regulation of competence for natural transformation in streptococci. Infect. Genet. Evol. 2015, 33, 343-360. [CrossRef] [PubMed]

4. Kleerebezem, M. Quorum sensing control of lantibiotic production; nisin and subtilin autoregulate their own biosynthesis. Peptides 2004, 25, 1405-1414. [CrossRef] [PubMed]

5. Le, K.Y.; Otto, M. Quorum-sensing regulation in staphylococci-an overview. Front. Microbiol. 2015, 6, 1174. [CrossRef] [PubMed]

6. Monnet, V.; Juillard, V.; Gardan, R. Peptide conversations in Gram-positive bacteria. Crit. Rev. Microbiol. 2014, 42, 339-351. [CrossRef]

7. Kalamara, M.; Spacapan, M.; Mandic-Mulec, I.; Stanley-Wall, N.R. Social behaviours by Bacillus subtilis: Quorum sensing, kin discrimination and beyond. Mol. Microbiol. 2018, 110, 863-878. [CrossRef]

8. Shanker, E.; Federle, M.J. Quorum Sensing Regulation of Competence and Bacteriocins in Streptococcus pneumoniae and mutans. Genes 2017, 8, 15. [CrossRef]

9. Rocha-Estrada, J.; Aceves-Diez, A.E.; Guarneros, G.; de la Torre, M. The RNPP family of quorum-sensing proteins in Gram-positive bacteria. Appl. Microbiol. Biotechnol. 2010, 87, 913-923. [CrossRef]

10. Neiditch, M.B.; Capodagli, G.C.; Prehna, G.; Federle, M.J. Genetic and structural analyses of RRNPP intercellular peptide signaling of Gram-positive bacteria. Annu. Rev. Genet. 2017, 51, 311-333. [CrossRef]

11. Pottathil, M.; Lazazzera, B.A. The extracellular Phr Peptide-Rap phosphatase signaling circuit of Bacillus subtilis. Front. Biosci. 2003, 8, 32-45. [CrossRef]

12. Slamti, L.; Perchat, S.; Huillet, E.; Lereclus, D. Quorum sensing in Bacillus thuringiensis is required for completion of a full infectious cycle in the insect. Toxins 2014, 6, 2239-2255. [CrossRef] [PubMed]

13. Dunny, G.M.; Berntsson, R.P. Enterococcal sex pheromones: Evolutionary pathways to complex, two-signal systems. J. Bacteriol. 2016, 198, 1556-1562. [CrossRef] [PubMed]

14. Declerck, N.; Bouillaut, L.; Chaix, D.; Rugani, N.; Slamti, L.; Hoh, F.; Lereclus, D.; Arold, S.T. Structure of PlcR: Insights into virulence regulation and evolution of quorum sensing in Gram-positive bacteria. Proc. Natl. Acad. Sci. USA 2007, 104, 18490-18495. [CrossRef] [PubMed]

15. Parashar, V.; Aggarwal, C.; Federle, M.J.; Neiditch, M.B. Rgg protein structure-function and inhibition by cyclic peptide compounds. Proc. Natl. Acad. Sci. USA 2015, 112, 5177-5182. [CrossRef] 
16. Lanigan-Gerdes, S.; Dooley, A.N.; Faull, K.F.; Lazazzera, B.A. Identification of subtilisin, Epr and Vpr as enzymes that produce CSF, an extracellular signalling peptide of Bacillus subtilis. Mol. Microbiol. 2007, 65, 1321-1333. [CrossRef]

17. Pomerantsev, A.P.; Pomerantseva, O.M.; Camp, A.S.; Mukkamala, R.; Goldman, S.; Leppla, S.H. PapR peptide maturation: Role of the NprB protease in Bacillus cereus 569 PlcR/PapR global gene regulation. FEMS Immunol. Med. Microbiol. 2009, 55, 361-377. [CrossRef]

18. Clewell, D.B.; Weaver, K.E.; Dunny, G.M.; Coque, T.M.; Francia, M.V.; Hayes, F. Extrachromosomal and Mobile Elements in Enterococci: Transmission, Maintenance, and Epidemiology. In Enterococci: From Commensals to Leading Causes of Drug Resistant Infection; Gilmore, M.S., Clewell, D.B., Ike, Y., Shankar, N., Eds.; Massachusetts Eye and Ear Infirmary: Boston, MA, USA, 2014.

19. Varahan, S.; Harms, N.; Gilmore, M.S.; Tomich, J.M.; Hancock, L.E. An ABC transporter is required for secretion of peptide sex pheromones in Enterococcus faecalis. MBio 2014, 5, e01726-14. [CrossRef]

20. Ibrahim, M.; Guillot, A.; Wessner, F.; Algaron, F.; Besset, C.; Courtin, P.; Gardan, R.; Monnet, V. Control of the transcription of a short gene encoding a cyclic peptide in Streptococcus thermophilus: A new quorum-sensing system? J. Bacteriol. 2007, 189, 8844-8854. [CrossRef]

21. Chang, J.C.; LaSarre, B.; Jimenez, J.C.; Aggarwal, C.; Federle, M.J. Two Group A streptococcal peptide pheromones act through opposing Rgg regulators to control biofilm development. PLoS Pathog. 2011, 7, e1002190. [CrossRef]

22. Chang, J.C.; Jimenez, J.C.; Federle, M.J. Induction of a quorum sensing pathway by environmental signals enhances group A streptococcal resistance to lysozyme. Mol. Microbiol. 2015, 97, 1097-1113. [CrossRef] [PubMed]

23. Junges, R.; Salvadori, G.; Shekhar, S.; Amdal, H.A.; Periselneris, J.N.; Chen, T.; Brown, J.S.; Petersen, F.C. A Quorum-Sensing System That Regulates Streptococcus pneumoniae Biofilm Formation and Surface Polysaccharide Production. mSphere 2017, 2. [CrossRef] [PubMed]

24. Pérez-Pascual, D.; Gaudu, P.; Fleuchot, B.; Besset, C.; Rosinski-Chupin, I.; Guillot, A.; Monnet, V.; Gardan, R. RovS and its associated signaling peptide form a cell-to-cell communication system required for Streptococcus agalactiae pathogenesis. MBio 2015, 6, e02306-e02314. [CrossRef] [PubMed]

25. Zhi, X.; Abdullah, I.T.; Gazioglu, O.; Manzoor, I.; Shafeeq, S.; Kuipers, O.P.; Hiller, N.L.; Andrew, P.W.; Yesilkaya, H. Rgg-Shp regulators are important for pneumococcal colonization and invasion through their effect on mannose utilization and capsule synthesis. Sci. Rep. 2018, 8, 6369. [CrossRef] [PubMed]

26. Mignolet, J.; Fontaine, L.; Sass, A.; Nannan, C.; Mahillon, J.; Coenye, T.; Hols, P. Circuitry rewiring directly couples competence to predation in the gut dweller Streptococcus salivarius. Cell Rep. 2018, 22, 1627-1638. [CrossRef] [PubMed]

27. Fleuchot, B.; Gitton, C.; Guillot, A.; Vidic, J.; Nicolas, P.; Besset, C.; Fontaine, L.; Hols, P.; Leblond-Bourget, N.; Monnet, V.; et al. Rgg proteins associated with internalized small hydrophobic peptides: A new quorum-sensing mechanism in streptococci. Mol. Microbiol. 2011, 80, 1102-1119. [CrossRef]

28. Gardan, R.; Besset, C.; Gitton, C.; Guillot, A.; Fontaine, L.; Hols, P.; Monnet, V. The extracellular life cycle of ComS, the competence stimulating peptide of Streptococcus thermophilus. J. Bacteriol. 2013, 195, 1845-1855. [CrossRef]

29. Khan, R.; Rukke, H.V.; Ricomini Filho, A.P.; Fimland, G.; Arntzen, M.O.; Thiede, B.; Petersen, F.C. Extracellular identification of a processed type II ComR/ComS pheromone of Streptococcus mutans. J. Bacteriol. 2012, 194, 3781-3788. [CrossRef]

30. Chang, J.C.; Federle, M.J. PptAB exports Rgg quorum-sensing peptides in Streptococcus. PLoS ONE 2016, 11, e0168461. [CrossRef]

31. Fontaine, L.; Boutry, C.; de Frahan, M.H.; Delplace, B.; Fremaux, C.; Horvath, P.; Boyaval, P.; Hols, P. A novel pheromone quorum-sensing system controls the development of natural competence in Streptococcus thermophilus and Streptococcus salivarius. J. Bacteriol. 2010, 192, 1444-1454. [CrossRef]

32. Schramma, K.R.; Bushin, L.B.; Seyedsayamdost, M.R. Structure and biosynthesis of a macrocyclic peptide containing an unprecedented lysine-to-tryptophan crosslink. Nat. Chem. 2015, 7, 431-437. [CrossRef]

33. Fleuchot, B.; Guillot, A.; Mézange, C.; Besset, C.; Chambellon, E.; Monnet, V.; Gardan, R. Rgg-associated SHP signaling peptides mediate cross-talk in streptococci. PLoS ONE 2013, 8, e66042. [CrossRef] [PubMed] 
34. Makarova, K.; Slesarev, A.; Wolf, Y.; Sorokin, A.; Mirkin, B.; Koonin, E.; Pavlov, A.; Pavlova, N.; Karamychev, V.; Polouchine, N.; et al. Comparative genomics of the lactic acid bacteria. Proc. Natl. Acad. Sci. USA 2006, 103, 15611-15616. [CrossRef] [PubMed]

35. Letort, C.; Juillard, V. Development of a minimal chemically-defined medium for the exponential growth of Streptococcus thermophilus. J. Appl. Microbiol. 2001, 91, 1023-1029. [CrossRef] [PubMed]

36. Gardan, R.; Besset, C.; Guillot, A.; Gitton, C.; Monnet, V. The oligopeptide transport system is essential for the development of natural competence in Streptococcus thermophilus strain LMD-9. J. Bacteriol. 2009, 191, 4647-4655. [CrossRef] [PubMed]

37. Biswas, I.; Gruss, A.; Ehrlich, S.D.; Maguin, E. High-efficiency gene inactivation and replacement system for gram-positive bacteria. J. Bacteriol. 1993, 175, 3628-3635. [CrossRef] [PubMed]

38. Débarbouillé, M.; Arnaud, M.; Fouet, A.; Klier, A.; Rapoport, G. The sacT gene regulating the sacPA operon in Bacillus subtilis shares strong homology with transcriptional antiterminators. J. Bacteriol. 1990, 172, 3966-3973. [CrossRef] [PubMed]

39. Martin, M. Cutadapt removes adapter sequences from high-throughput sequencing reads. EMBnet J. 2011, 17, 3. [CrossRef]

40. Li, H.; Durbin, R. Fast and accurate short read alignment with Burrows-Wheeler transform. Bioinformatics 2009, 25, 1754-1760. [CrossRef]

41. Nicolas, P.; Bize, L.; Muri, F.; Hoebeke, M.; Rodolphe, F.; Ehrlich, S.D.; Prum, B.; Bessières, P. Mining Bacillus subtilis chromosome heterogeneities using hidden Markov models. Nucleic Acids Res. 2002, 30, 1418-1426. [CrossRef]

42. Ibrahim, M.; Nicolas, P.; Bessières, P.; Bolotin, A.; Monnet, V.; Gardan, R. A genome-wide survey of short coding sequences in streptococci. Microbiology 2007, 153, 3631-3644. [CrossRef] [PubMed]

43. Liao, Y.; Smyth, G.K.; Shi, W. featureCounts: An efficient general purpose program for assigning sequence reads to genomic features. Bioinformatics 2014, 30, 923-930. [CrossRef] [PubMed]

44. Love, M.I.; Huber, W.; Anders, S. Moderated estimation of fold change and dispersion for RNA-seq data with DESeq2. Genome Biol. 2014, 15, 550. [CrossRef] [PubMed]

45. Anders, S.; Huber, W. Differential expression analysis for sequence count data. Genome Biol. 2010, 11, R106. [CrossRef] [PubMed]

46. Benjamini, Y.; Hochberg, Y. Controlling the false discovery rate: A practical and powerful approach to multiple testing. J. R. Stat. Soc. Ser. B 1995, 57, 289-300. [CrossRef]

47. Altschul, S.F.; Madden, T.L.; Schaffer, A.A.; Zhang, J.; Zhang, Z.; Miller, W.; Lipman, D.J. Gapped BLAST and PSI-BLAST: A new generation of protein database search programs. Nucleic Acids Res. 1997, 25, 3389-3402. [CrossRef] [PubMed]

48. Boutry, C.; Wahl, A.; Delplace, B.; Clippe, A.; Fontaine, L.; Hols, P. Adaptor protein MecA is a negative regulator of the expression of late competence genes in Streptococcus thermophilus. J. Bacteriol. 2012, 194, 1777-1788. [CrossRef]

49. Thévenard, B.; Besset, C.; Choinard, S.; Fourcassié, P.; Boyaval, P.; Monnet, V.; Rul, F. Response of S. thermophilus LMD-9 to bacitracin: Involvement of a BceRS/AB-like module and of the rhamnose-glucose polysaccharide synthesis pathway. Int. J. Food Microbiol. 2014, 177, 89-97. [CrossRef]

50. Schilcher, K.; Caesar, L.K.; Cech, N.B.; Horswill, A.R. Processing, export, and identification of novel linear peptides from Staphylococcus aureus. mBio 2020, 11, e00112-e00120. [CrossRef]

51. Cheng, D.; Lv, H.; Yao, Y.; Cheng, S.; Huang, Q.; Wang, H.; Liu, X.; Bae, T.; Li, M.; Liu, Q. Roles of the Site 2 Protease Eep in Staphylococcus aureus. J. Bacteriol. 2020, 202. [CrossRef] [PubMed]

52. Brown, M.S.; Ye, J.; Rawson, R.B.; Goldstein, J.L. Regulated intramembrane proteolysis: A control mechanism conserved from bacteria to humans. Cell 2000, 100, 391-398. [CrossRef]

53. Martin, B.; Quentin, Y.; Fichant, G.; Claverys, J.P. Independent evolution of competence regulatory cascades in streptococci? Trends Microbiol. 2006, 14, 339-345. [CrossRef] [PubMed]

54. Wang, C.Y.; Medlin, J.S.; Nguyen, D.R.; Disbennett, W.M.; Dawid, S. Molecular determinants of substrate selectivity of a pneumococcal Rgg-regulated peptidase-containing ABC transporter. mBio 2020, 11, e02502-e02519. [CrossRef] [PubMed]

55. Junges, R.; Sturod, K.; Salvadori, G.; Amdal, H.A.; Chen, T.; Petersen, F.C. Characterization of a signaling system in Streptococcus mitis that mediates interspecies communication with Streptococcus pneumoniae. Appl. Environ. Microbiol. 2019, 85, e02297-18. [CrossRef] [PubMed] 
56. Fernandez, A.; Borges, F.; Thibessard, A.; Gintz, B.; Decaris, B.; Leblond-Bourget, N. Characterisation of Streptococcus thermophilus CNRZ368 oxidative stress-resistant mutants: Involvement of a potential Rgg-like transcriptional regulator. Le Lait 2004, 84, 77-85. [CrossRef]

57. Aggarwal, C.; Jimenez, J.C.; Nanavati, D.; Federle, M.J. Multiple length peptide-pheromone variants produced by Streptococcus pyogenes directly bind Rgg proteins to confer transcriptional regulation. J. Biol. Chem. 2014, 289, 22427-22436. [CrossRef]

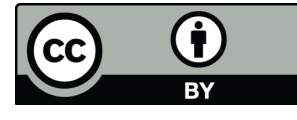

(C) 2020 by the authors. Licensee MDPI, Basel, Switzerland. This article is an open access article distributed under the terms and conditions of the Creative Commons Attribution (CC BY) license (http://creativecommons.org/licenses/by/4.0/). 